\title{
MUTUAL INFLUENCES BETWEEN MOTHERHOOD AND EDUCATIONAL ATTAINMENT IN SELECTED EASTERN EUROPEAN COUNTRIES
}

\author{
CORNELIA MUREȘAN1
}

\begin{abstract}
Women are spending an ever longer part of their lives enrolled in education programs. A crucial question in this context is how motherhood can be reconciled and correlated with continued investment in human capital. A related question concerns the role the socioeconomic context plays in the education/ family life balance. In the present study we account for the finding that a pregnancy resulting in a first birth usually triggers the termination of formal education, and, conversely, that the completion of education is often followed by a first birth. We use a simultaneous-hazard two-equation model, controlling for common potential but unobserved determinants. Relative to work already done on these matters, our study extends previous investigations to Eastern European countries which have not been adequately researched so far. To strengthen comparison, we have additionally included two Western European countries. This allowed us to assess the importance of political context. The results show that despite efforts to offer women the possibility of choosing both motherhood and being enrolled in education, the educational policies which were introduced in some Eastern European countries after the fall of communist political regimes could not counteract the negative effects of the transition to a market economy. In these formerly communist countries, the continuation of studies in parallel with childbearing and family formation has become more difficult.
\end{abstract}

Keywords: educational attainment, first birth, simultaneous processes, mutual endogeneity, Eastern Europe, Generations and Gender Surveys

\footnotetext{
1 Faculty of Sociology and Social Work, Babeș-Bolyai University Cluj-Napoca, e-mail: cornelia.muresan@socasis.ubbcluj.ro.
} 


\section{Background $^{2}$}

The massive educational expansion of recent decades is one of the most fundamental social changes in Europe in modern times. Not only has the number of students grown steadily, but the number of years that a student spends in higher education has also increased considerably (OECD, 2013). As women who study and graduate from higher education programs enter motherhood later in life than other women, if they enter at all (Beaujouan, Brzozowska and Zeman, 2016), the extended education is usually seen as an important factor in the postponement of a first birth.

The correlation between the steady increase in the duration of studies and the postponement of motherhood in Europe is easy to notice. According to Eurostat data, the mean age of women at first birth has gone up in all former communist countries from about 23-24 years in 1998, to about 25-27 years in 2010 (Figure 1), approaching the higher mean age at transition to motherhood in Western Europe. The same development can be observed in the dynamic of the duration of studies. During the calendar interval 1998 - 2010 the number of years expected to be spent in tertiary education (Figure 2) increased dramatically in Eastern Europe. In some Eastern European countries this envisioned study duration became even higher than in Norway or in France. Before the political turnover in the former communist countries, tertiary education was fully subsidized by a relatively poor welfare state which drastically limited the number of available places in tertiary education, correlated this number with the needs of the national economy, and guaranteed employment for all graduates. Thus, a small proportion of the young population could occupy the few places offered by the universities. This situation changed after the political turnover, when the number of places in universities skyrocketed, a process paralleled by the demise of guaranteed jobs at the completion of education (graduation). The Eastern countries are, in this respect, quite different from their wealthier Western counterparts, in which being enrolled in tertiary studies and, consequently, having a high level of education, became mainstream by the beginning of the 1990s.

\footnotetext{
${ }^{2}$ I am grateful to Francesco Billari for pointing out the need to study concomitantly the mutual impact between education and fertility. My gratitude goes also toward Jan M. Hoem, Gerda Neyer, Gunnar Andersson, and the anonymous reviewers for their suggestions concerning new literature related to the topic and necessary improvements to increase the pertinence of this study. This work was supported by a grant of the Romanian National Authority for Scientific Research, CNCS-UEFISCDI, project number PN-II-ID-2011-3-0145.
} 
MUTUAL INFLUENCES BETWEEN MOTHERHOOD AND EDUCATIONAL ATTAINMENT IN SELECTED ...

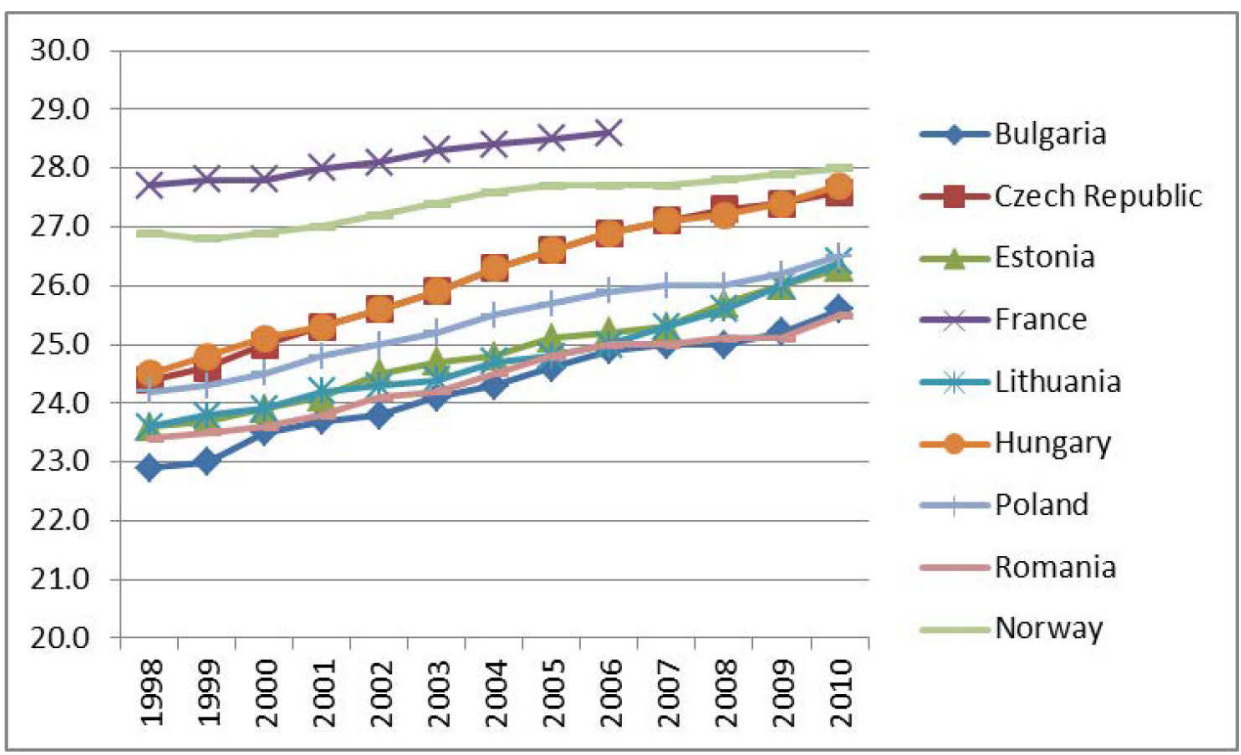

Figure 1. Mean age of women at birth of first child, 1998-2010, selected European countries Source: Eurostat (2018). Author's graph.

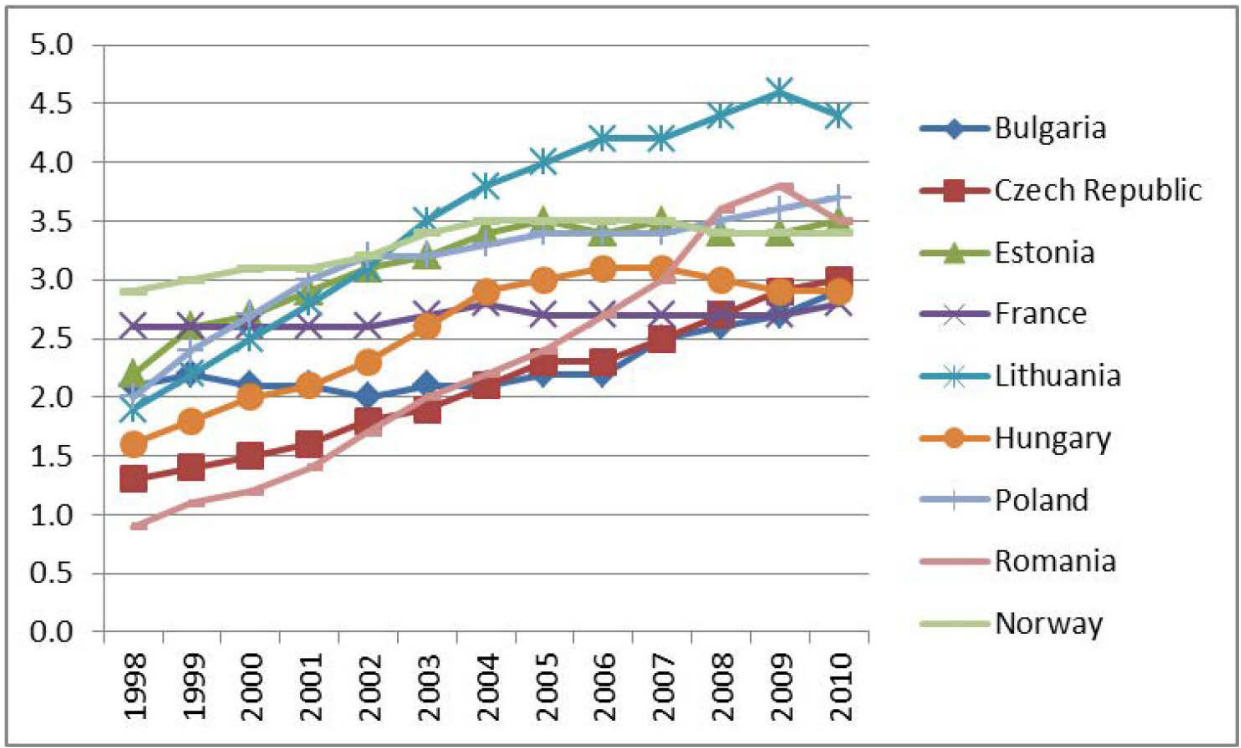

Figure 2. Expected years of tertiary education (ISCED 5-6), 1998-2010, selected European countries Source: Eurostat (2018). Author's graph. 
With the development of these two processes, and the extended overlap in age span at enrolment in higher education and family formation, it becomes clear that research into how motherhood can (or cannot) be reconciled with continued investment in human capital is more important than ever, as are investigations of the role the socioeconomic context plays in the education/ family balance. The present paper contributes to this growing body of literature.

\section{Theoretical considerations}

The general tenor in the relevant scientific literature is that very early motherhood usually has negative consequences for a woman's later life, particularly when she gives birth to her first child while she is still enrolled in education. For a young woman, a birth increases the risk of terminating education because of the pressing need to care for child and family. This basic observation is well documented in the literature, for example in an early study conducted by Lillard et al. (1994). These authors simultaneously studied several events of family formation and educational career and found that 'women who became pregnant in their "current" schooling decision window were much less likely to go on the next grade level' (Lillard et al., 1994: 42). This was found true also for women attending college.

Macro-level circumstances can attenuate or even reverse these negative consequences. Notably, the flexibility of the educational system (Hoem et al., 2006), cultural factors of family solidarity (Dalla Zuanna, 2001; Billari, 2004; Billari and Philipov, 2004a), and social policies designed to facilitate the combination of student and parental roles (Rindfuss, 1991; Hoem, 1993; EspingAndersen, 1999; McDonald, 2000; Gauthier, 2002; Thalberg, 2013) may modulate the impact of pregnancy and motherhood on educational enrolment. Our broad choice of countries for investigation has the purpose of capturing a wide range of such possibilities. We are particularly interested in Eastern Europe, because in this region the educational system suffered numerous changes and reform attempts (Eurydice, 2015; PERFAR, 2014). These transformations accompanied the political and socio-economic transition from communist regimes to democracy and market economy. Starting with the 1990s, many new fields of study were introduced, the number of state funded places in public universities increased, numerous private universities were created in which students paid for their education, etc. The result was that the proportion of young people continuing their studies in higher education increased tremendously. Around the turn of the millennium, new forms of education like open \& distance learning and reduced frequency tertiary education began to emerge everywhere in the former communist countries (Rădulescu, 2006; Sławiński and Dębowski, 2013), allowing the continuation or resuming of studies for those who wanted to combine university enrolment with family life and professional activity. 
The major inconvenient in the study of the effect of childbearing on educational attainment is that the direction of causation is not clear. The literature has shown that in most populations a first birth usually triggers the end of education and, conversely, that the birth of a first child is triggered by the completion of education. An investigation of the causal effect of either of these two processes on the other generally needs a study of both processes simultaneously because of their mutual endogeneity. Therefore several authors have modelled together educational enrolment and childbearing in various manners. For example, Gerster et al. (2013) used Danish register data to show that the relationship between education and completed fertility is the result of a dynamic interplay between the two processes. Similarly, Tesching (2012) dealt with the interrelationship between women's educational level, educational field, and first and higher order births, while Thalberg (2013) handled students' enrolment and childbearing. Both of the latter studies used Swedish longitudinal register data and took into consideration not only the interplay between the two processes, but also the impact of common unobserved factors on educational trajectories and fertility decisions. MartinGarcia and Baizan (2006) studied the impact of educational enrolment and the type of education on first births using Spanish Family and Fertility Survey data by jointly considering the end of education and the entry into parenthood, again controlling for common unmeasured heterogeneity. The importance of the mutual influence of educational enrolment and first birth, the relative weight of common factors, and the role of welfare regimes have all been assessed for eleven Western European countries by Billari and Philipov (2004a) on the basis of 1990s data in the Family and Fertility Survey, and by Brand and Davis (2011) with data from the U.S. National Longitudinal Survey of Youth from 1979. Billari and Philipov have found important international differences in micro-level relationships: the mutual influence and the importance of common factors for both processes are weaker where welfare regimes, and in particular social policies that allow role combination, are stronger. Disaggregating the effects of college by propensity score strata, Brand and Devis have found that the fertilitydecreasing college effect is concentrated among women from comparatively disadvantaged social backgrounds and low levels of early achievement. The effects of college on fertility attenuate as we observe women from backgrounds that are more predictive of college attendance and completion.

Our purpose is to extend such investigations to Eastern Europe, using as far as possible individual-level dynamics of the processes involved, as reflected in the latest Generation and Gender Surveys data sets that cover any former communist country. We aim to investigate whether it has been easier to combine studies with childbearing in some countries in this region than in 
others, how similar the former communist countries have been to each other in these respects, and how they differ from two of West European countries (France and Norway). We also want to explore whether the combination of educational enrolment with childbearing has become easier over time, since one of the aims of social policies in many European countries is to help people attain their various life goals related to different domains of their life course.

We formulate two research hypotheses, as follows:

H1. Conception and birth during studies increase women's risk of terminating education. The impact is stronger at times when and in societies where welfare regimes provide less support to a role combination or to a postponement of the end of education.

The latter means that we expect a stronger negative impact of childbearing on completing education in market economy times than during communist regimes in Eastern Europe, since the developments of educational systems toward making possible the combination between education, family and work, are more recent than the functioning of market economy rules, which more often force individuals to choose between education, work and family. It also means that we should see a stronger impact in general in Eastern Europe than in the two Western countries, where the integrative educational policies have a longer history.

H2. In more family-oriented welfare regimes (e.g. in Romania) and in societies with a more pronounced de-standardization of the life course (e.g. in Norway), the correlation between unobserved factors that affect both the length of education and the time to motherhood is lower.

Personal values, preferences, perceptions about role incompatibility, sense of personal efficacy, egalitarian gender role attitudes are all considered, in our study, as unobserved factors affecting both the length of education and the time to motherhood. Thus, career-oriented women could use higher education for professional gain and consequently limit fertility, while familyoriented women with lower labour market prospects deem motherhood their means to personal fulfilment. Our assumption is that the correlation between propensity for motherhood and for educational attainment is lower in societies where the compatibility between these two parallel processes finds more support either by the families or by the welfare policies. 


\section{Data and methods}

For any empirical study of the interaction between educational attainment and fertility, the two factors need to be well defined, i.e. they have to be made more precise than in the general reasoning above, and they need to be related to the data at hand. Gerster and her collaborators (2013) represented fertility by the number of children ultimately born by a respondent in their register data, and they defined educational attainment in terms of five educational levels for which the individual had a record of completing the needed examination or degree. Most other authors have used some continuous representation of the individual childbearing histories instead, and have applied a simpler version of time-varying educational histories. We have chosen yet another (original) strategy, in accordance with our data capabilities.

For each of our own country-specific analyses we have selected information from the first-round national Generations and Gender survey (GGS) and have used a simultaneous-hazard two-equation analysis, controlling for unobserved heterogeneity. Because of our particular interest in Eastern Europe, we have used GGS data from seven former-communist countries in that region (Bulgaria, Czech Republic, Estonia, Hungary, Lithuania, Poland, and Romania), and for comparison we have also selected GGS data for two countries in Western Europe (France and Norway). To our knowledge, the GGS data for the East European countries have never been studied systematically in this manner before.

For each national data set we have followed enrolled and childless female respondents from age 17 to 35 , between January $1^{\text {st }} 1980$ and the date of the interview. Details about national sample sizes, interview dates, and numbers and shares of events are shown in Table 1.

As it is well known, major political changes took place in Eastern Europe in 1989-1990, with important consequences for the welfare regimes in the region. In our analyses we have therefore distinguished three periods: the 1980s (the last years of the communist authoritarian regimes), the first eight years of transition (1990-1997), and the last seven to fourteen available years (19982004/11, varying between countries), representing the consolidated capitalist regime.

For the two West European countries, both with stable socio-political regimes, the comparative analysis by period reveals the dynamics of the mutual relationship between the transition to motherhood and the end of studies, and it could highlight, should it be the case, the differences with Eastern Europe, a region which so far has received less attention than it deserves. 
Table 1.

Interview dates, sample sizes, numbers of events, and share of first conceptions/births before the end of education

\begin{tabular}{|l|l|l|c|c|c|c|c|c|}
\hline & $\begin{array}{l}\text { Interview } \\
\text { date }\end{array}$ & $\begin{array}{c}\text { Sample } \\
\text { size }\end{array}$ & $\begin{array}{c}\text { End of } \\
\text { education }\end{array}$ & $\begin{array}{c}\text { Conceptions } \\
\text { before end } \\
\text { of } \\
\text { education }\end{array}$ & $\begin{array}{c}\text { Birth } \\
\text { before } \\
\text { end of } \\
\text { education }\end{array}$ & $\begin{array}{c}\text { Total } \\
\text { first } \\
\text { birth }\end{array}$ & $\begin{array}{c}\text { Conception } \\
\text { before end } \\
\text { of } \\
\text { education, } \\
\text { \% }\end{array}$ & $\begin{array}{c}\text { Birth } \\
\text { before } \\
\text { end of } \\
\text { education, } \\
\text { \% }\end{array}$ \\
\hline Former communist countries \\
\hline Bulgaria & $\begin{array}{l}\text { Oct.-Dec. } \\
\text { 2004 }\end{array}$ & 3426 & 2760 & 718 & 602 & 2223 & 21 & 18 \\
\hline Czech R. & $\begin{array}{l}\text { Feb.2004- } \\
\text { Nov.2005 }\end{array}$ & 2228 & 1667 & 254 & 188 & 1196 & 11 & 8 \\
\hline Estonia & $\begin{array}{l}\text { Sep.2004- } \\
\text { Dec.2005 }\end{array}$ & 2011 & 1622 & 526 & 420 & 1418 & 26 & 21 \\
\hline Hungary & $\begin{array}{l}\text { Nov.2004- } \\
\text { May 2005 }\end{array}$ & 2558 & 2569 & 330 & 275 & 1467 & 13 & 11 \\
\hline Lithuania & $\begin{array}{l}\text { Apr.-Dec. } \\
\text { 2006 }\end{array}$ & 2082 & 1439 & 511 & 436 & 1269 & 25 & 21 \\
\hline Romania & $\begin{array}{l}\text { Nov.-Dec. } \\
\text { 2005 }\end{array}$ & 1761 & 1449 & 259 & 225 & 1194 & 15 & 13 \\
\hline Poland & $\begin{array}{l}\text { Jan.2010- } \\
\text { Dec.2011 }\end{array}$ & 5081 & 3852 & 1103 & 923 & 3369 & 22 & 18 \\
\hline Democratic countries & & & & & & & \\
\hline France & $\begin{array}{l}\text { Sep.2004- } \\
\text { Dec.2005 }\end{array}$ & 2356 & 1812 & 218 & 194 & 1210 & 9 & 8 \\
\hline Norway & $\begin{array}{l}\text { Jan.2007- } \\
\text { Oct.2008 }\end{array}$ & 3863 & 2843 & 919 & 855 & 1210 & 24 & 22 \\
\hline
\end{tabular}

Source: Author's synthesis based on the Gender and Generations Survey (GGS).

Notes: National samples of childless women who were enrolled at least one month during age interval $17-35$. The period of investigation starts from the beginning of 1980 until the interview date.

\section{Analytic strategy}

Following the approach outlined by Lillard (1993), we have used a simultaneous-hazard two-equation model to assess the reciprocal impact of the first conception (leading to birth) and the end of educational enrolment, controlling for potentially common determinants through unobserved heterogeneity. This heterogeneity incorporates the effect of individual characteristics, values and norms that remain largely unchanged until the first birth or the end of education, whichever comes later. One should note that, like most survey data, the GGSs do not contain continuous information about values and norms at the time 
when a woman is exposed to the risks of pregnancy or at completion of education, so we must use an indirect methodology. Since value orientations usually do change to some extent during an individual's life, we did not want to use the only information concerning values that the GGS collected, namely attitudes and opinions manifested at the time of the interview. Initially we also included two easily available common control variables to represent a woman's observed characteristics, namely her number of siblings and her type of region of residence at age 15, but we ended up dropping these variables when they turned out not to give much further insight.

To spell this out, we have proceeded as follows: We have modelled the intensity $h_{E}(t)$ of the transition to the successful end of education and the intensity $h_{B}(t)$ of the transition to motherhood (actually 7 months before the time of first birth), using a system of two hazard equations. For both intensities, we have let process time start at age 17 , which is when enrolled people usually are close to completing high school and to deciding whether to continue or not with tertiary education. We have preferred not to start at younger ages (say, at age 15 as it is usual for assessing risks of a first birth, or at age 10 as it is usual for assessing the end of education) in order to avoid as much as possible the mismatch between completing or dropping out of education on the one hand, and to make sure we dealt with a more deliberate decision of young women to choose between family formation and continuing studies on the other. The two situations may be influenced very differently by the factors under study. We censor all life histories at age 35. The calendar months of the two defining events were recorded in the GGS data. (In the Norwegian data, educational attainment was collected from register data.)

Model 1

We have used the following model:

$$
\begin{aligned}
& \ln \mathrm{h}_{\mathrm{E}}(\mathrm{t})=\mathrm{y}_{\mathrm{E}}(\mathrm{t})+\mathrm{C}(\mathrm{a}(0)-1980+\mathrm{t})+\alpha_{1} \mathrm{M}(\mathrm{t})+\alpha_{2} \mathrm{U}(\mathrm{t})+\tau_{1}, \\
& \ln \mathrm{h}_{\mathrm{B}}(\mathrm{t})=\mathrm{y}_{\mathrm{B}}(\mathrm{t})+\mathrm{C}(\mathrm{a}(0)-1980+\mathrm{t})+\beta_{1} \mathrm{E}(\mathrm{t})+\beta_{2} \mathrm{U}(\mathrm{t})+\tau_{2} .
\end{aligned}
$$

As an alternative, we have sometimes used the following model instead: Model 2

$$
\begin{aligned}
& \ln \mathrm{h}_{\mathrm{E}}(\mathrm{t})=\mathrm{y}_{\mathrm{E}}(\mathrm{t})+\alpha_{1} \mathrm{M}(\mathrm{t})^{*} \mathrm{P}(\mathrm{t})+\alpha_{2} \mathrm{U}(\mathrm{t})+\tau_{1}, \\
& \ln \mathrm{h}_{\mathrm{B}}(\mathrm{t})=\mathrm{y}_{\mathrm{B}}(\mathrm{t})+\beta_{1} \mathrm{E}(\mathrm{t})^{*} \mathrm{P}(\mathrm{t})+\beta_{4} \mathrm{U}(\mathrm{t})+\tau_{2} .
\end{aligned}
$$

The functions included in the models are as follows:

$y_{E}(t)$ and $y_{B}(t)$ denote the baseline effects of age $t$ from 17 to 35 years, represented by the logarithm of a linear duration spline with knots every two years for the intensity of end of education, and at ages 20,25, and 30 for the intensity of first birth. These apply when the other functions have the value 0 . 
$C(a(0)-1980+t)$ is a second duration spline which captures the effect of calendar time. It is expressed relative to the year 1980. The argument $a(0)$ is the calendar year when individual $i$ starts to be exposed to risk, i.e. the year when the person reaches age 17. It is a duration spline with two knots, located at January $1^{\text {st }} 1990$, and January $1^{\text {st }} 1998$. This term appears only in Model 1.

$P(t)$ is a time-varying variable denoting the calendar period, specified as 1 for the 1980s, 2 for 1990 -1997, and 3 for the period from 1998 to the date of interview, as already noted. It is used in Model 2 where it is interacted with other terms.

$M(t)$ is a time-varying variable denoting current maternal status, with three possibilities: 'childless so far (i.e., at age $t$ )', 'childless and pregnant', and 'mother'.

$U(t)$ is a dichotomous time-varying variable indicating first-union formation (counting either marriage or non-marital cohabitation).

$E(t)$ is also a time-varying variable denoting educational attainment, with three statuses: 'in education', 'out of education, middle level of education or less attained' and 'out of education, high level of education attained'.

In Model 2 we have included interactions between the maternal status variable and period, and between educational attainment and period, in order to shed light on the way the reciprocal effect of motherhood and education changes between periods.

The items $\tau_{1}$ and $\tau_{2}$ are normally distributed unobserved characteristics of the individual with variance equal to 1 and a correlation of $\rho$ between the unobserved characteristics. The parameter $\rho$ is estimated in each national data set. We have fixed the variances of the unobserved heterogeneity items $\tau_{1}$ and $\tau_{2}$ to 1 , forced by the fact that for some countries the iterative estimation process with unknown variances did not converge in our data. Other authors, like Tesching (2012), Baizan et al. (2003), and Martin-Garcia and Baizan (2006), have allowed the heterogeneity factors to have general variances which they have estimated, but they found that it does not much matter for their results (in their Swedish and Spanish data, respectively) whether the variances were set to 1 or were estimated. The effects of observed covariates were essentially the same in both cases. Other authors, like Billari and Philipov (2004b), argue that variances must be fixed to 1 when events are not repeatable, as in our case, where we study first births only. Their standpoint is likely coloured by the need to have identifiable heterogeneity items.

For the estimation of the hazard models we have used the aML software, Version 2.09 (Lillard and Panis 2003). 
For each specification of our model elements, we fit a pair of hazards to the data for nine countries, which meant that we operated with eighteen regressions each time we fit the models. To limit the amount of work, we focused on first births alone. We kept the multiplicity of possibilities in check by 'only' operating with first unions in the specification of the union covariate $U(t)$ and by 'only' using the specification of the motherhood covariate $M(t)$ where we censor educational histories at age 35 . As we shall see when we present our results below, these restrictions did not prevent us from arriving at extensive new findings about (first) childbearing in Eastern Europe.

Note that in all our various specifications, the two processes (completion of education and first birth) appear in an asymmetric manner in our analysis. While the intensity $h_{B}(t)$ of first birth operates on each female respondent only as long as the first birth has not yet occurred, her intensity $h_{E}(t)$ of successful termination of educational enrolment continues to act after the first birth and until censoring.

\section{Results}

\section{Trends of first births intensities}

Before we assess the influence of the transition to motherhood on the completion of education, and conversely the effect of leaving education on childbearing, let us look at the development of the two phenomena over time separately (Figures 3 and 4).

After an increase between 1980 and 1990 in most countries, first-births risks decreased in all countries, reaching a value $20-80 \%$ lower at the interview dates relative to that at the beginning of 1980 (Figure 1). The decrease was rather steep and started in most countries after 1990. In Romania, childbearing postponement started ten years earlier, in the 1980s (see also Mureșan et al., 2008; Mureșan and Hoem, 2010). A key contribution to the lower first birth hazard in 1990 as compared to 1980 in Romania is the effect of abrogation of the 1966 decree on the prohibition of contraceptives and abortion. France is the mirror image of the Romanian case - at least regarding trends observed after the 1980s -, postponement started ten years later than in the rest of the countries we cover. We cannot see any pattern substantially separating the Eastern European countries from the selected Western countries. 


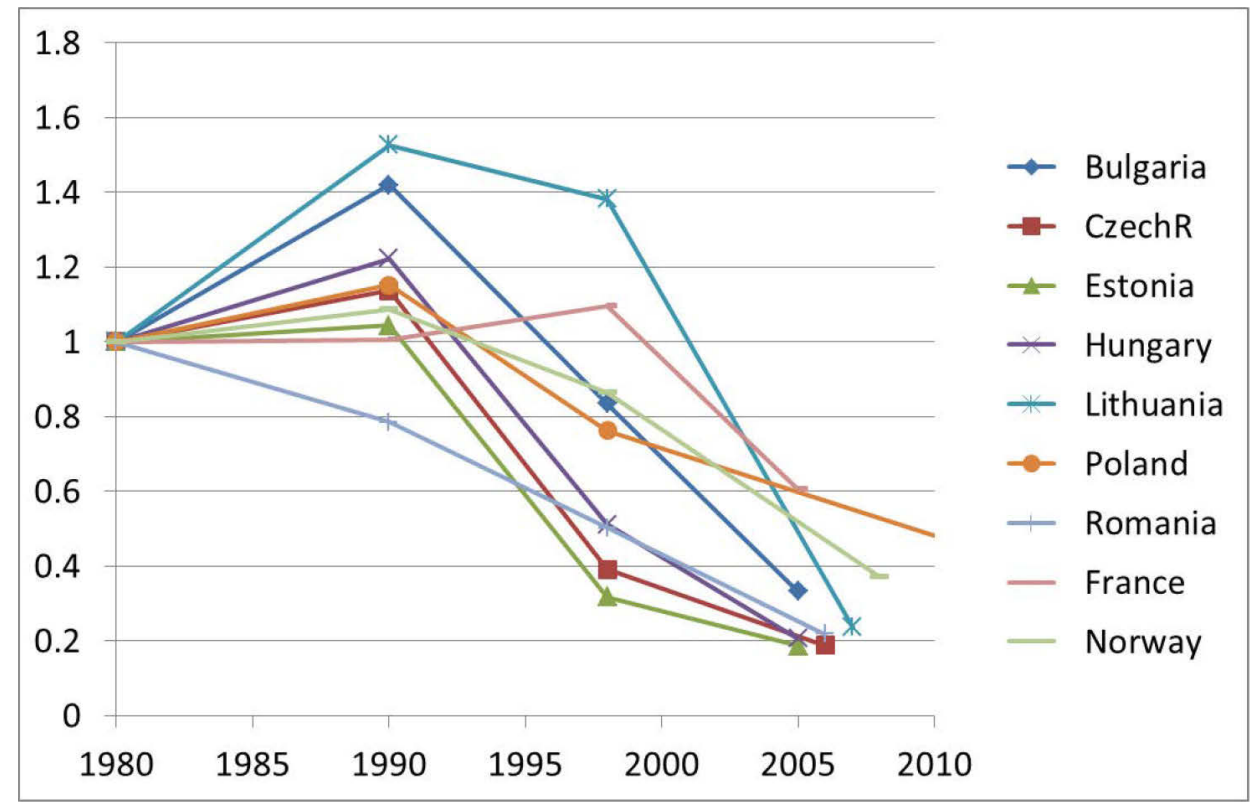

Figure 3. Trends in country-specific hazards of first birth (relative to 1980). Childless women who were enrolled at least one month during age interval $17-35$. Duration splines by calendar year

Source: Author's calculations and graph based on the GGS dataset.

\section{Trends in completion of education}

In what regards the transition to the end of education, the general trend (Figure 4) shows decreasing intensities (and thus longer study durations) during the 1990s, and essentially much smaller changes after 1998.

Here, the true exception is Norway, where one can see a persistently increasing intensity of completion of education. The exceptional case of Norway was also noted by Cohen, Kravdal, and Keilman (2011) in a sophisticated analysis showing that the direction of causation between educational attainment and final family size is from fertility to education. However, this particular finding cannot be extended to other countries. For example, Ni Bhrolchain and Beaujouan (2012) argue that fertility postponement is largely due to rising educational enrolment, at least in France and Britain, the two countries they studied. This would mean that causation goes from education to fertility. We have been able to show, as will be presented in the following, that the direction of causation between first birth and completion of education in more recent times in Eastern Europe is also from education to fertility. 


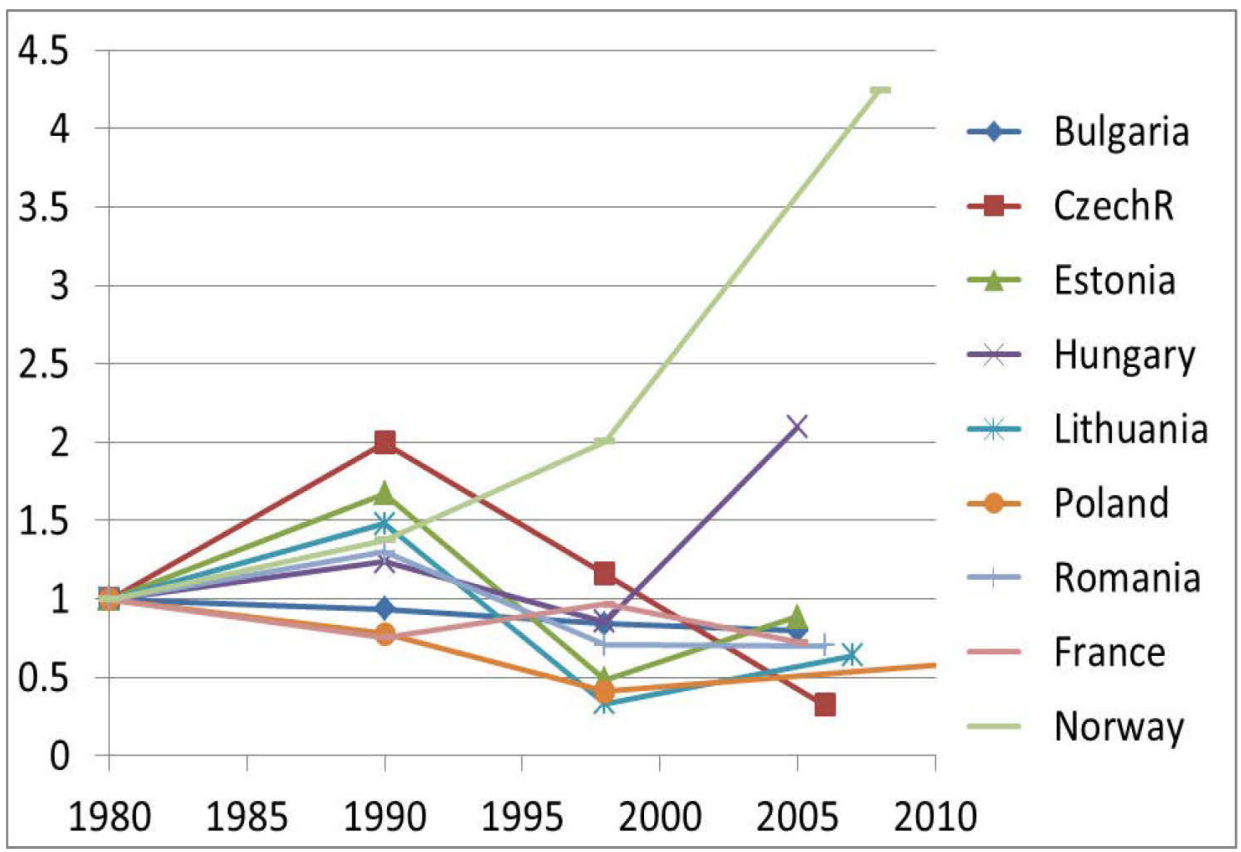

Figure 4. Trends in hazards of completion of education (relative to 1980). Childless women who were enrolled at least one month during age interval 17 - 35. Duration splines by calendar year

Source: Author's calculations and graph based on the GGS dataset.

\section{Overall mutual influences}

Table 2 displays the results of fitting Model 1: relative risks of transition to the end of education, and relative risks of transition to a first birth, for the overall period and controlling for unobserved heterogeneity. The first two lines of the table, which contain the results of the effects of first conception and of first birth on the duration of studies (enrolled women), are given a visual representation in Figure 5.

Figure 5 shows that that a pregnancy (ending in a live birth) significantly increased the risk of terminating education in only two East European countries (Estonia and Poland). A birth during studies reduced significantly the risk of terminating education in all countries, as it is natural that these women returned to the educational system after the end of their parental leave. A stronger impact is found in three former communist countries (Bulgaria, Czech Republic, and Hungary), but also in France and Norway. It seems that in this respect Eastern Europe presents no distinct pattern compared to Western Europe. 
Table 2.

Results of country-specific simultaneous-hazard models of transition to the end of education and of transition to a first birth (relative risks from Model 1). Censoring seven months before any second birth or at age 35

\begin{tabular}{|c|c|c|c|c|c|c|c|c|c|}
\hline & BG & $\mathbf{C Z}$ & EE & HU & LT & RO & PL & FR & NO \\
\hline \multicolumn{10}{|c|}{ Transition to end of education } \\
\hline \multicolumn{10}{|c|}{ Maternal status (no children so far=1) } \\
\hline $\begin{array}{l}\text { Pregnant } \\
\text { (1=childless) }\end{array}$ & 1.03 & 0.93 & 1.74 & 1.07 & 1.15 & 1.29 & 1.36 & 0.73 & 0.86 \\
\hline Mother (1=childless) & 0.46 & 0.49 & 0.67 & 0.46 & 0.63 & 0.65 & 0.58 & 0.41 & 0.43 \\
\hline \multicolumn{10}{|l|}{ First union (no=1) } \\
\hline yes & 1.82 & 1.17 & 1.17 & 1.14 & 1.36 & 1.25 & 1.40 & 1.43 & 1.25 \\
\hline \multicolumn{10}{|c|}{ Transition to first birth } \\
\hline \multicolumn{10}{|c|}{ Educational status (in education=1) } \\
\hline $\begin{array}{l}\text { lo/mid. level, out of } \\
\text { ed. }\end{array}$ & 1.15 & 2.43 & 2.15 & 1.54 & 1.84 & 1.83 & 1.95 & 1.43 & 2.12 \\
\hline hi level, out of ed. & 1.16 & 2.13 & 1.57 & 1.46 & 1.57 & 1.03 & 1.41 & 1.06 & 1.92 \\
\hline \multicolumn{10}{|l|}{ First union (no=1) } \\
\hline yes & 33.90 & 7.59 & 19.72 & 11.74 & 21.71 & 25.15 & 14.85 & 17.29 & 10.60 \\
\hline$p$ & 0.40 & 0.18 & 0.04 & 0.42 & -0.02 & -0.02 & 0.25 & 0.53 & 0.01 \\
\hline
\end{tabular}

Note. Significant values are given in boldface.

Source: Author's calculations based on the GSS dataset.

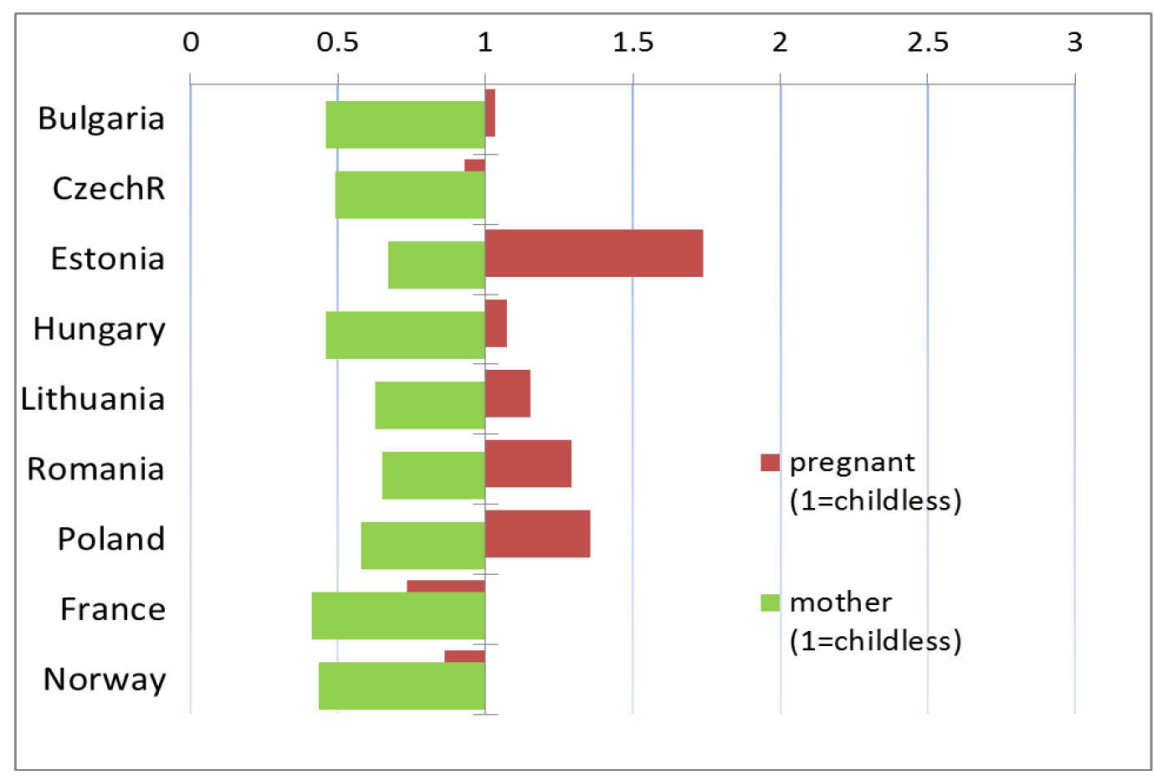

Figure 5. Relative risks of ending education by maternal status.

Source: Author's calculations and graph based on the GGS dataset. 
Entering a first union significantly increased the risk of terminating education in most of our countries. The increase was about one quarter in Estonia, Romania, and Norway; it was between $40-80 \%$ in Bulgaria, Lithuania, Poland, and France (see Table 2, last line in the upper half). For Hungary and Estonia, the results are not statistically significant. In all countries, the role of first union formation in the transition to motherhood was much stronger, first birth risk being higher by 8 to 34 times (from Czech Republic to Bulgaria) than for those not yet in any union (see the last line in the bottom half of Table 2).

Beside the evidence of the role of union formation, our estimates in the model of transition to first birth (bottom half of Table 2) show another almost universal impact, namely a significantly lower childbearing risk among enrolled women, especially when compared with women with a completed middle level of education or less. Only in Bulgaria it seems that the educational attainment had no significant impact on first birth risk, but in this case the influence of entering a first union was the biggest and potentially overwhelmed the effect of education. As many authors have noted (Billari and Philipov, 2004a; Blossfeld and Huinink, 1991; Kravdal, 1994; Hoem, 1986; Hoem and Hoem, 1989, Rindfuss et al., 1980), the level of education does not play a major role in childbearing when we control for enrolment. This is the case for five out of nine countries from our study. However, in the other half, namely in the case with women in Estonia, Romania ${ }^{3}$, Poland, and France ${ }^{4}$, the situation is not the same, and more recent studies show that the level of education has a key role in childbearing (Mureșan and Hoem, 2010; Ní Bhrolcháin and Beaujouan, 2012). In these four countries, a tertiary education sensibly reduced the risk of a first birth when compared to a middle level of education; and in Romania and France the risks were as low as those of women who are still enrolled.

\footnotetext{
${ }^{3}$ More details about the Romanian negative educational gradient in parity-specific fertility are reported by Mureșan and Hoem (2010).

${ }^{4}$ Ní Bhrolcháin and Beaujouan (2012) found that in France, first birth postponement is mainly 'attributable to the rise in educational participation, but the additional lengthening of the time to first birth not explained by rising educational enrolment is related to educational level, with the best educated women postponing their births for longer following the end of education than other groups'.
} 


\section{Common effects of personal characteristics and value orientation on educational trajectories and the timing of motherhood}

Estimated correlation coefficients ${ }^{5}$ of unobserved heterogeneity are positive and statistically significant for Bulgaria, Hungary, and Poland, three of the former communist countries, as well as in the case of France which has a conservative welfare regime (last line of Table 2). In the Czech Republic the coefficient is also positive, but not statistically significant. In each case this indicates the prevalence of unobserved common factors that affected both processes in the same direction, i.e. an unobserved orientation towards a career prolonged both the length of education and delayed transition to motherhood.

The fact that the correlation coefficients are close to zero in the remaining countries may indicate that personal characteristics and value orientations matter less for the combination of investments in education with family life and motherhood. This is the case for Romania and the countries from the former Soviet bloc (Estonia and Lithuania), three countries with pronounced familyoriented regime, but also for Norway, a country where the social-democratic welfare regime has induced a de-standardization of the life-course. In the latter mentioned countries the personal values, preferences, perceptions about role incompatibility, sense of personal efficacy, egalitarian gender role attitudes are less correlated either because of strong family support (in the Eastern European countries), or because of efficient welfare policies (in Norway). Note that a consideration of the national correlation coefficients does not result after all in a clustering of the Eastern European countries; they do not form a distinct region.

\section{Changes in the effects of motherhood on education}

Results of applying Model 2 (Figure 6) show how the impact of pregnancy and motherhood on educational enrolment changes over time.

For the 1980s, we found significantly higher risks of terminating education among pregnant women only for Estonia. In contrast to the Estonian case, in Poland, France and Norway pregnancy decreased these risks and prolonged the duration of studies. Meanwhile the risk of leaving education among enrolled mothers was significantly lower in 5 out of the 9 countries in our set: Bulgaria, Hungary, Poland, among the Eastern countries, and also France and Norway, the two Western countries we studied.

\footnotetext{
5 We have also fitted similar models for the two transitions without terms for unobserved heterogeneity. The results (not shown in Table 2) indicate in general higher mutual effects in countries with significant positive correlations between the two unobserved factors, and lower effects for the other countries.
} 
MUTUAL INFLUENCES BETWEEN MOTHERHOOD AND EDUCATIONAL ATTAINMENT IN SELECTED ...

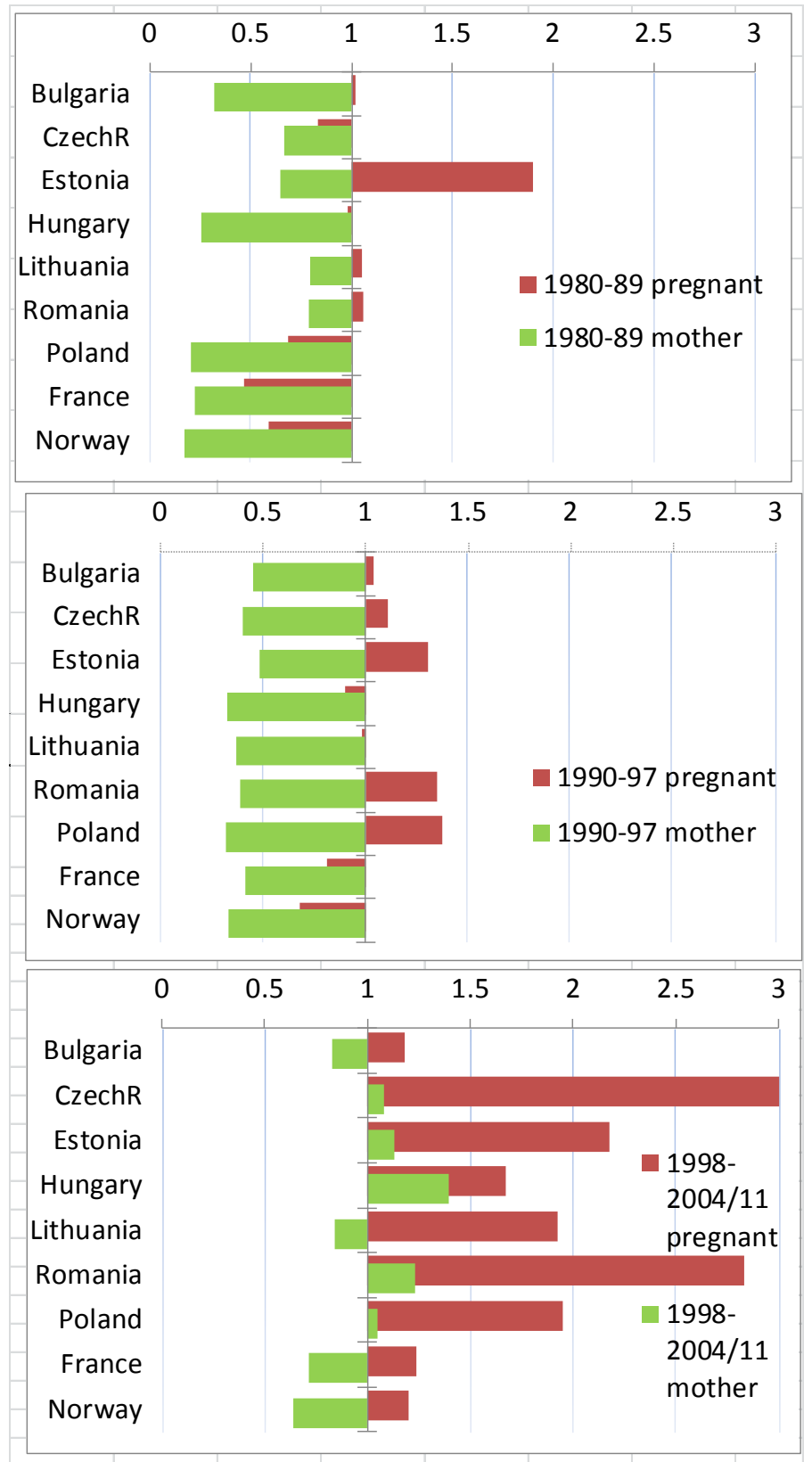

Figure 6. Relative risks of end of education by maternal status and period (versus no children so far). Model 2.

Source: Author's calculations and graph based on the GGS dataset. 
In the early 1990s, pregnancy had no effect on the duration of education, but motherhood definitely increased the duration of studies in all the countries we investigated. It seems that everywhere it was easier to combine education and family formation between 1990-1997 than before or after this period.

The opposite may be observed in Eastern Europe for the years around 2000. Motherhood did not induce prolonged studies anymore; moreover, in this period a pregnancy determined to a large extent the end of education almost everywhere (the sole exception being Bulgaria). In the two Western European countries we used as benchmark, the positive influence of motherhood on duration of education persisted over time ${ }^{6}$. This is the only systematic difference we found between the behaviour of women in Eastern and Western Europe.

\section{Changes in the effects of education on motherhood}

In what regards the change over time in the effects of educational attainment on the transition to motherhood, the results from the analysis we performed using Model 2 (Figure 7) show that a first birth is triggered uniformly by the completion of education. This effect is generally stronger when the level of education attained is below tertiary education. There are very few exceptions i.e. some countries, in specific periods, where there are no significant differences concerning first birth risks between students and women with a completed education. Such examples are Bulgaria and France in the 1980s, and Bulgaria, France and Hungary in the 1990s.

In all the countries we covered, in the years around 2000, the already higher risks of transition to motherhood for women who had completed their education (compared to enrolled women) further increased by 2-4 times. Thus, the main pattern in more recent times is that both in Eastern and Western Europe the reduction in birth intensities is due mainly to increased educational enrolment. The level of education introduces further differences in half of the countries we covered: some of the Eastern European set (Estonia, Lithuania, Poland, and Romania) and one of the Western pair (France).

\footnotetext{
${ }^{6}$ Note that the formerly positive effect of pregnancy loses its significance and even becomes negative.
} 


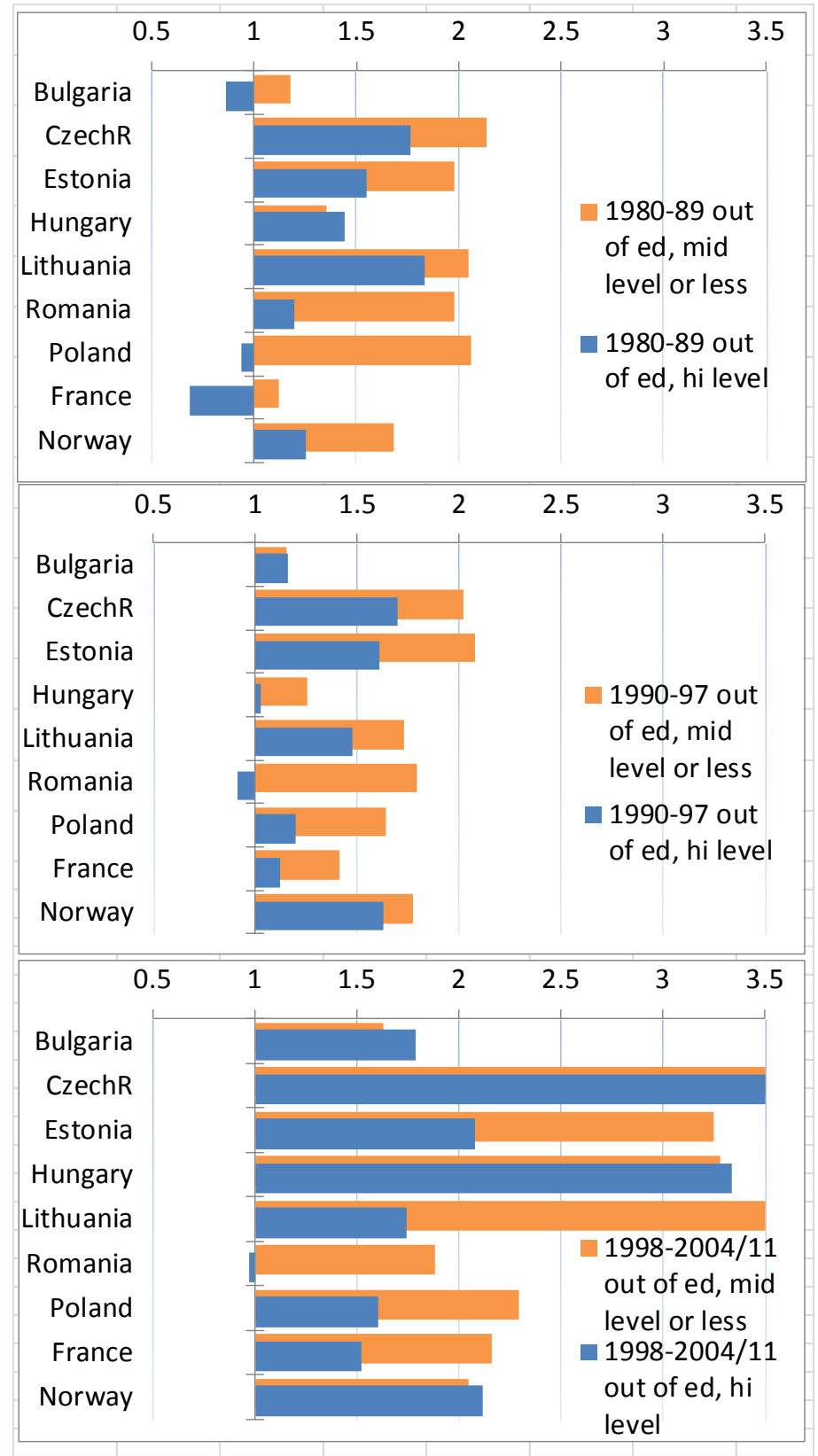

Figure 7. Relative risks of first birth by educational status and period (versus still in education). Model 2.

Source: Author's calculations and graph based on the GGS dataset. 


\section{Conclusions}

We started this paper by indicating a number of research questions and hypotheses. In what regards the question of where it was easier to combine enrolment in education with childbearing, we have seen that in general a pregnancy could be combined with enrolment in both Eastern Europe and Western Europe (with Estonia as the only exception). Moreover, once a birth occurred before the completion of studies, a woman tended to prolong her studies. Overall, between 1980 and 2004/11, Eastern Europe does not manifest a pattern distinct from that of Western Europe: pregnancy during studies had no effect on the duration of education, motherhood before the end of education prolonged the duration of studies, enrolment strongly reduced the risk of transition to motherhood, while the effect of attained level of education on postschooling fertility was smaller.

However, the situation changed around the year 2000. In East European countries reconciling motherhood and education became much more difficult. This was not the case in the two Western European countries. Our initial expectation that the combination of educational enrolment with childbearing became easier over time is thus not supported by the available evidence. In fact, the contrary seems to be true: In the former communist countries, pregnancy during studies began to trigger the termination of education, while motherhood during studies lost its influence on prolonging the duration of studies. The Western European countries instead maintained their privileged situation: they were friendlier when it came to combining motherhood and studies, even if a pregnancy did not lead to prolonged studies to the same extent as it had done before. Note however that everywhere, in all countries (former-communist or not), enrolment remained hardly compatible with motherhood, and most first births occurred after the completion of education.

It seems that the 2000s were more demanding in terms of combining educational investments, professional career, and family life; this was especially true in Eastern European countries. Despite educational policies designed to facilitate the return to studies - e.g. distance learning tertiary education programs were introduced in most Eastern European countries at the end of the 1990s - pregnant women tended to decide to end their studies, while mothers generally failed to restart education. Another explanation could be that women learned to plan better their time of transition to motherhood and linked it to the time of finishing education: they planned births very close to the moment when they completed the studies or they planned conceptions soon after completion of studies. Thus, it seems that the recent fertility postponement was due mainly to rising educational enrolment, both in Eastern 
and in Western Europe. In the post-communist countries however motherhood postponement was also due to the lack of efficient family and educational policies to facilitate combining motherhood and education - i.e. policies able to counteract the negative effects of the transition to a market economy. In these cases, the continuation of studies in parallel with childbearing and family formation became much more difficult.

Our first hypothesis, which claimed that conception and birth during studies increase the risk of terminating education, has not been entirely confirmed for all countries and all periods. It is true for pregnancy in Estonia and Poland, but for the other Eastern European countries it is true only in more recent times. Unlike in Eastern Europe, in the two Western European countries investigated, pregnancy did not have any influence on terminating studies. This can be contrasted with the effect of motherhood. Motherhood before completing education did not increase the risk of terminating studies anywhere. On the contrary, it prolonged studies everywhere and for all periods we investigated.

Our second research hypothesis is, on the other hand, entirely confirmed. Unobserved personal orientation toward a career - a factor that both prolongs the length of education and delays the transition to motherhood -, respectively personal orientation toward family - a factor that both triggers motherhood and shorten the length of education - played a significant role in four of the nine countries in our set: three East European (Bulgaria, Hungary, and Poland) and one West European (France). In the other former-communist countries (Estonia, Lithuania, and Romania; perhaps also in Czech Republic), the correlation between unobserved factors that affect both the length of education and the time to motherhood was less important, maybe because in these countries family solidarity was stronger, and permitted young mothers to continue their studies while grandparents usually took care of their grandchildren. Note however that a personal value orientation toward family and education did not show any correlation in Norway either, perhaps because its social-democratic welfare regime facilitated the compatibility between motherhood and education, and thus permitted a de-standardization of the life-course.

\section{REFERENCES}

Baizan, P., Aassve, A., and Billari, F.C. (2003). Cohabitation, marriage, and first birth: The interrelationship of family formation events in Spain. European Journal of Population, 19(2): 147-169. 
Beaujouan, E., Brzozowska, Z. and Zeman, K. (2016). The limited effect of increasing educational attainment on childlessness trends in twentieth-century Europe, women born 1916-65. Population Studies, 70:3, 275-291.

Billari, F.C. (2004). Becoming an adult in Europe: A Macro(/Micro)-Demographic Perspective. Demographic Research SC, 3(2): 15-44.

Billari, F.C. and Philipov, D. (2004a). Education and the transition to motherhood: A comparative analysis of Western Europe. European Demographic Research Papers 3.

Billari, F.C., and Philipov, D. (2004b). Women's education and entry into first union. A simultaneous-hazard comparative analysis of Central and Eastern Europe. Vienna Yearbook of Population Research, 91-110.

Blossfeld, H.P. and Huinink, J. (1991). Human capital investments or norms of role transition? How women's schooling and career affect the pro-cess of family formation. American Journal of Sociology, 97(1): 143-168.

Brand, J.E., and Davis, D. (2011). The Impact of College Education on Fertility: Evidence for Heterogeneous Effects. Demography, 48(3): 863-887.

Cohen, J.E., Kravdal, O. and Keilman, N. (2011). Childbearing impeded education more than education impeded childbearing among Norwegian women, Proceedings of the National Academy of Sciences of the United States of America, 108(29): 11830-11835.

Dalla Zuanna, G., 2001. The banquet of Aeolus: A familistic interpretation of Italy's lowest low fertility. Demographic Research, 4 (5): 133-162.

Esping-Andersen, G. (1999). Social Foundations of Post-Industrial Economies. New York: Oxford University Press.

Eurydice (2015) https://webgate.ec.europa.eu/fpfis/mwikis/eurydice/index.php/Countries, European Commission (Accessed 1.10.2015).

Gauthier, A.H. (2002). Family Policies in Industrialized Countries: Is there Convergence? Population English Edition, 57(3): 457 - 484.

Gerster, M., Ejrnæs, M., and Keiding N. (2013). The Causal Effect of Educational Attainment on Completed Fertility for a Cohort of Danish Women - Does Feedback Play a Role? Statistics in Biosciences. 5(1): 1-22.

Hoem, J. (1986). The Impact of Education on Modern Family-Union Initiation. European Journal of Population, 2(2): 113-133.

Hoem, J. (1993). Public policy as the fuel of fertility: effects of a policy re-form on the pace of childbearing in Sweden in the 1980s. Acta Sociologica, 36(1): 19-31.

Hoem, B. and Hoem, J. (1989). The Impact of Women's Employment on Second and Third Births in Modern Sweden. Population Studies, 43(1): 47-67.

Hoem, J., Neyer, G. and Andersson, G. (2006). Education and childlessness: The relationship between educational field, educational level, and childlessness among Swedish women born in 1955-59. Demographic Research, 14(15): 331-380.

Kravdal, Ø. (1994). The importance of economic activity, economic potential and economic resources for the timing of first births in Norway. Population Studies, 48(2): 249-267. 
Lillard, L.A. (1993). Simultaneous equations for hazards: Marriage duration and fertility timing. Journal of Econometrics, 56(1-2): 189-217.

Lillard, L.A., Panis, C. and Upchurch, D. (1994). Interdependencies Over the Life Course: Women's Fertility, Marital, and Educational Experiences. Santa Monica, CA: RAND Corporation. http://www.rand.org/pubs/drafts/DRU763.

Lillard, L.A. and Panis C. (2003). aML Multilevel Multiprocess Statistical Software, Version 2.0. EconWare, Los Angeles, California.

Martín-García, T., and Baizán, P. (2006). The Impact of the Type of Education and of Educational Enrolment on First Births. European Sociological Review, 22(3): 259-275.

Matysiak, A. (2009). Employment first, then childbearing: Women's strategy in postsocialist Poland, Population Studies, 63(3): 253-276.

McDonald, P. (2000). Gender Equity, Social Institutions and the Future of Fertility. Journal of Population Research, 17(1): 1-16.

Mureșan, C. and Hoem, J.M. (2010). The negative educational gradients in Romanian fertility. Demographic-Research, 22(4): 95-114.

Mureșan, C., Hărăguș, P.-T., Hărăguș, M., and Schröder, C. (2008). Overview Chapter 6: Romania: Childbearing metamorphosis within a changing context. Demographic Research, 19(23): 855-906.

Ní Bhrolcháin, M. and Beaujouan, E. (2012) Fertility postponement is largely due to rising educational enrolment, Population Studies, 66:3, 311-327.

OECD (2013). Education at a Glance 2013. OECD Indicators. OECD Publishing. Retrieved from http://dx.doi.org/10.1787/eag-2013-en (Accessed 01.10.2015).

PERFAR (2014). Collection of Family Policies of the Population Europe Resource Finder and Archive, www.perfar.eu/policy/education/ (Accessed 1.10.2015).

Rădulescu, D.C. (2006). Invățământul românesc 1948-1989 - între derivă și recuperare institutional-funcțională [The Romanian educational system between 1948 and 1989 between drifting and institutional-functional recovery), Calitatea Vieții, XVII (3-4): 307-318.

Rindfuss, R. (1991). The young adult years: Diversity, structural change, and fertility. Demography, 28(4): 493-512.

Rindfuss, R. R., Bumpass, L. and St.John, C. (1980). Education and Fertility: Implications for the Roles Women Occupy. American Sociological Review, 45: 431-447.

Sławiński, S., H. Dębowski (2013). Referencing Report. Referencing the Polish Qualifications Framework for Lifelong Learning to the European Qualifications Framework, Warsaw: Instytut Badań Edukacyjnych.

Tesching K. (2012). Education and Fertility. Dynamic Interrelations between Women's Educational Level, Educational Field and Fertility in Sweden, Acta Universitatis Stockholmiensis, Stockholm University Demography Unit - Dissertation Series 6.

Thalberg, S. (2013). Students and Family Formation. Studies on educational enrolment and childbearing in Sweden, Acta Universitatis Stockholmiensis, Stockholm University Demography Unit - Dissertation Series 9. 